\title{
Enzyme Immobilization: An Overview on Nanoparticles as Immobilization Matrix
}

\section{Razi Ahmad and Meryam Sardar}

Department of Biosciences, Jamia Millia Islamia, New Delhi-110025, India

*Corresponding author: Meryam Sardar, Department of Biosciences, Jamia Millia Islamia, New Delhi-110025, India, Tel: +91 9818200995; E-mail: msardar@jmi.ac.in Rec date: Feb 06, 2015; Acc date: May 04 2015; Pub date: May 06, 2015

Copyright: $\odot 2015$ Ahmad R, et al. This is an open-access article distributed under the terms of the Creative Commons Attribution License, which permits unrestricted use, distribution, and reproduction in any medium, provided the original author and source are credited.

Abstract
Immobilization process is to optimize the operational performance of an enzyme for industrial applications. So far
different matrices have been described in the literature to improve the performance of the immobilized enzymes.
With the advent of nanotechnology, the nanomaterials because of their unique physico-chemical properties
constitute novel and interesting matrices for enzyme immobilization. The nanomaterials possess ideal characteristics
to equilibrate principal factors which determine biocatalysts efficiency, including specific surface area, mass transfer
resistance and effective enzyme loading. This review presents the current scenario and techniques in enzyme
immobilization. An overview of the main methods used to combine proteins/enzymes with nanoparticles is given in
the study. The advantages and disadvantages of nanoparticles as immobilization matrix are also discussed.

Keywords: Immobilization; Nanoparticles; Covalent attachment; Adsorption; Crosslinking

\section{Introduction}

Enzymes are catalyst that catalysis many biochemical and chemical reactions. They are universally present in plants and animals. Due to their ease of production, substrate specificity and green chemistry these biocatalyst are widely used in diverse sections. Enzymes have extensive applications in food industries such as baking [1,2], dairy products [3], starch conversion [4] and beverage processing (fruit, vegetable juices, beer and wine) [5]. In textile industries, they have found a special place due to their effect on end products [6]. In industries such as paper and pulp making [7] and detergents [8], the use of enzymes has become a necessary processing strategy. Some of the major class of industries such as health care \& pharmaceuticals [9] and chemical [10] manufacturing have been increased due to the catalytic nature of enzymes. Another major application of enzymes is in waste management [11] especially for solid wastes treatment [12] and waste water purification [13-15]. Past few years have marked the significance of enzymes in production of biofuels such as biodiesel, bioethanol, biohydrogen and biogas from biomass conversion [16]. However, all these desirable characteristics of enzymes and their widespread industrial applications are often obstructing by their lack of long-term operational stability, shelf life and by their recovery \& reusability. Enzyme immobilization is one of the strategies to overcome these problems.

\section{Enzyme immobilization}

Immobilized enzyme was discovered in 1916 [17]. It was demonstrated that activity of invertase enzyme does not get hampered when it is adsorbed on a solid matrix, such as charcoal or an aluminum hydroxide. This aspect led to the development of currently available enzyme immobilization techniques. Initially immobilization techniques used to have very low enzyme loadings, with respect to available surface areas. In late 90 s various covalent methods of enzyme immobilization were developed. While enzyme immobilization has been studied for a number of years, the appearance of recent published research and review papers indicates a continued interest in this area $[18,19]$. Currently commercial application of immobilized enzyme have been enhanced as they are highly efficient [5,19]. Further, its resistance to various environmental changes such as $\mathrm{pH}$ or temperature has been increased during immobilization of enzyme on solid support [20]. Compared to their free forms, immobilized enzymes are generally more stable and easier to handle. In addition, the reaction products are not contaminated with the enzyme which is useful in the food and pharmaceutical industries. Moreover, in the case of proteases, the rate of the autolysis process can be dramatically reduced upon immobilization only, if a multipoint or multisubunit immobilization is achieved, or if a favourable enzyme environment is obtained [21]. Additionally, immobilization also improves many properties of enzymes such as performance in organic solvents, $\mathrm{pH}$ tolerance, selectivity, heat stability or the functional stability. Increasing the structural rigidity of the protein and stabilization of multimeric enzymes prevents dissociation-related inactivation [22,23]. The attached enzyme is again ready for the subsequent reactions without the need for repeated, time consuming, and costly extraction and purification procedures [22]. These alterations result from structural changes introduced into the enzyme molecule by the applied immobilization procedure and from the creation of a microenvironment in which the enzyme works, different from the bulk solution [24]. The main objective of enzyme immobilization is to maximize the advantages of enzyme catalysis, which is possible by using a support with low synthesis cost and high binding capacity [25].

The stability of a native enzyme (non-immobilized) is principally determined by its intrinsic structure whereas the stability of an immobilized enzyme is highly dependent on many factors, including the nature of its interaction with the carrier, binding position and number of bonds, the freedom of the conformation change in the matrix, the microenvironment in which the enzyme molecule is located, the chemical and physical structure of the carrier, the properties of the spacer (for example, charged or neutral, hydrophilic or hydrophobic, size, length) linking the enzyme molecules to the 
carrier, and the conditions under which the enzyme molecules were immobilized. Hence the stability of the immobilized enzymes with respect to time, temperature and other storage conditions and experimental variables might be expected to either increase or decrease on immobilization [26]. It has been found that many enzymes immobilized by different immobilization techniques have higher activity than the native enzymes. For instance, epoxy hydrolase adsorbed on DEAE-cellulose by ionic bonding was more than twice as active as the native enzyme [27], lipase-lipid complex entrapped in nvinyl-2-pyrrolidone gel matrix was 50fold more active than the native enzyme [28]. Activation by immobilization is, however, often regarded as an additional benefit rather than a rational goal of enzyme immobilization. Activity retention by carrier-bound immobilized enzymes is usually approximately 50\%. At high enzyme loading, especially, diffusion limitation might occur as a result of the unequal distribution of the enzyme within a porous carrier, leading to a reduction of apparent activity [29]. The conditions for high activity retention are often marginal, thus often requiring laborious screening of immobilization conditions such as enzyme loading, $\mathrm{pH}$, carrier and binding chemistry [26]. Changes in enzyme properties not necessarily mean improvements, and in some instances a careful and extremely mild immobilization protocol should be used to keep the good properties of the utilized enzyme intact.

Immobilization of enzyme can be carried out by different methods; broadly they are classified as physical and chemical. Physical methods have weak interactions between matrix and enzyme, whereas in chemical methods there is formation of covalent bond between the support and the enzyme. In particular, the development and applications of site selective protein immobilization have undergone significant advances in recent years. It has been noticed that advances in organic chemistry and molecular biology have led to the development of some very powerful, efficient, site-specific, and important applications of anchoring proteins onto supports [30-32]. These have been followed by the development of functional protein microarrays, biosensors, and continuous flow reactor systems [31].

\section{Methods of immobilization}

The selection of mode of immobilization is very important to prevent the loss of enzyme activity by not changing the chemical nature or reactive groups in the binding site of enzyme. Considerable knowledge for the nature of the active site of the enzyme will be helpful. On the other hand, active site can be protected by the attachment of protective groups, later on which can be removed without any loss of enzyme activity. In some cases, this protective function can be fulfilled by a substrate or a competitive inhibitor of the enzyme. The most common procedures of enzyme immobilization are adsorption, covalent coupling, entrapment and cross-linking [18] Figure 1 gives the diagrammatic representation of the various methods of immobilization.

Although various reviews are published on the immobilization methods which give the detailed methodology, protocol of each method and also its advantages and disadvantages. A brief discussion of each method is summarized below.

Adsorption: Adsorption of enzymes onto insoluble supports is a very old and simple method which has wide application and high capability enzyme loading relative to other immobilization methods. Enzymes can be immobilized by simply mixing the enzymes with a suitable adsorbent, under appropriate conditions of $\mathrm{pH}$ and ionic strength. After washing off loosely bound and unbound enzyme, the immobilized enzyme is obtained in a directly usable form. Adsorption process is based on vander Waal forces, ionic and hydrogen bonding as well as hydrophobic interactions, which are very weak forces, but in large number, impart sufficient binding strength.

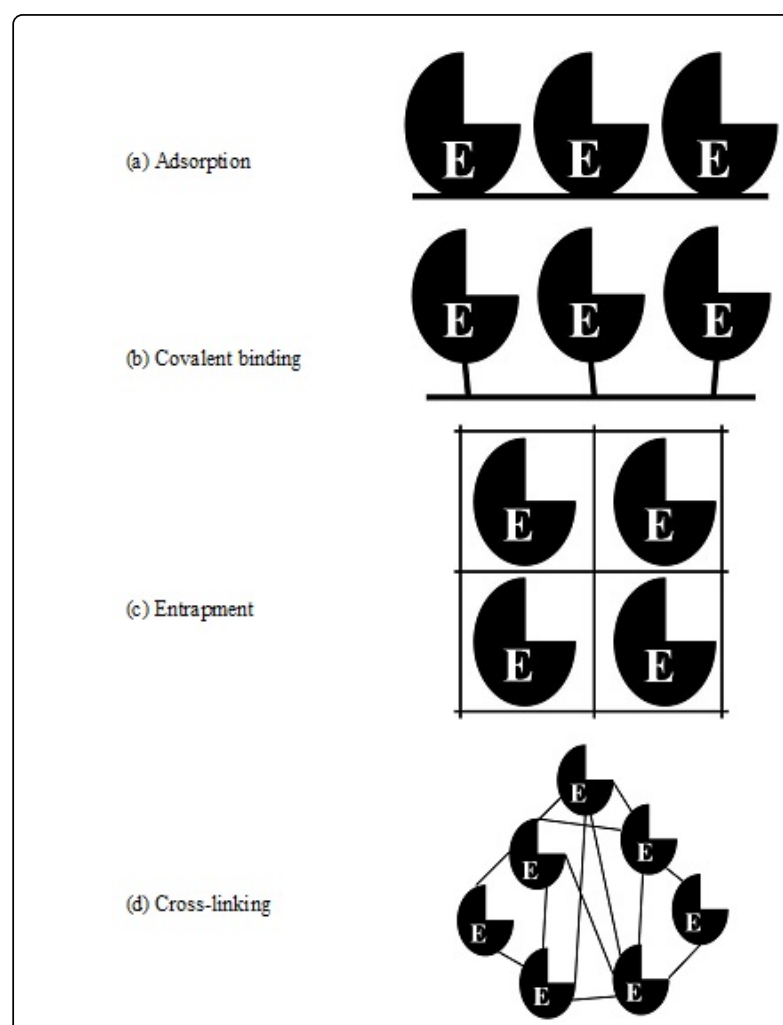

Figure 1: Diagrammatic representation of the various methods of enzyme immobilization.

Adsorbed enzymes can be protected from agglomeration, proteolysis and interaction with hydrophobic interfaces [33]. The choice of adsorbent particularly depends upon minimizing the leakage of used enzyme. In order to prevent chemical modification and damage to enzyme, the existing surface properties of enzymes and support are need to be considered Care must be taken that the binding forces are not weakened during use of unusual changes in $\mathrm{pH}$ or ionic strength. The adsorption through physical method generally leads to major changes in the protein microenvironment, and typically involves multipoint protein adsorption between a single protein molecule and a number of binding sites on the immobilization surface [34]. The main disadvantage of this method is that the enzyme is easily desorbed by factors like temperature fluctuations, changes in substrate and ionic concentrations [35].

Covalent binding: Covalent immobilization involves the formation of covalent bonds between the enzyme and the support matrix. The functional groups present in the enzymes get linked to support matrix as these functional group are not responsible for the catalytic activity. The binding reaction must be performed under conditions that do not cause loss of enzymatic activity, and the active site of the enzyme must be unaffected by the reagents used. Covalent association of enzymes to supports occurs owing to their side chain amino acids like arginine, aspartic acid, histidine and degree of reactivity based on different functional groups like imidazole, indolyl, phenolic hydroxyl, etc. [36]. 
Peptide-modified surfaces when used for enzyme linkage results in higher specific activity and stability with controlled protein orientation [37]. Sometimes functional groups on the support material are activated by certain reagents and enzyme is then coupled to the support material via covalent linkage. Cyanogen bromide $(\mathrm{CNBr})$ agarose and $\mathrm{CNBr}$-activated-Sepharose containing carbohydrate moiety and glutaraldehyde as a spacer arm have imparted thermal stability to covalently bound enzymes [38,39]. The connection between the carrier and enzyme can be achieved either by direct linkage between the components or via an intercalated link of differing length, which is called spacer. The spacer molecule gives a greater degree of mobility to the coupled biocatalyst so that its activity can be enhanced when compared to that of direct coupled biocatalyst.

Entrapment: It is defined as the restricted movement of enzymes in a porous gel, yet keeping them as free molecules in solution. Entrapment of enzymes within gels or fibers is a convenient method for use in processes involving low molecular weight substrates and products. However, the difficulty which large molecules have in approaching the catalytic sites of entrapped enzymes precludes the use of entrapped enzymes with high molecular weight substrates. The entrapment process may be a purely physical caging or involve covalent binding. Enzymes have been entrapped in natural polymers like agar, agarose and gelatine through thermo reverse polymerization, but in alginate and carrageenan by ionotropic gelation [40]. A number of synthetic polymers like polyvinylalcohol hydrogel [41], polyacrylamide [42] have also been investigated.

Cross-linking: This method involves attachment of biocatalysts to each other by bi- or multifunctional reagents or ligands [40]. In this way, very high molecular weight typically insoluble aggregates are formed. Cross-linking is a relatively simple process. It is not a preferred method of immobilization as it does not use any support matrix. So they are usually gelatinous and not particularly firm. Since it involves a bond of the covalent kind, biocatalyst immobilized in this way frequently undergoes changes in conformation with a resultant loss of activity. Still it finds good use in combination with other support dependent immobilization technologies, namely to minimize leakage of enzymes already immobilized by adsorption. The most commonly used bifunctional agent for cross-linking is glutaraldehyde. The reactive aldehyde groups at the two ends of glutaraldehyde react with free amino groups of enzymes through a base reaction and have been extensively used in view of its low cost, high efficiency, and stability. The enzymes or the cells have been normally cross-linked in the presence of an inert protein like gelatine, albumin, and collagen and can be applied to either enzymes or cells. The main disadvantages are the undesirable activity losses that can arise from the participation of catalytic groups in the interactions responsible for the immobilization. The cross-linking reaction is not easily controlled and so it is very difficult to obtain large enzyme aggregates with high activity retention. The gelatinous physical nature of the immobilized enzyme preparations is a great limitation in many applications. The more recently developed cross-linked enzyme aggregates (CLEAs) are produced by simple precipitation of the enzyme from aqueous solution, as physical aggregates of protein molecules, by the addition of salts, or water miscible organic solvents or non-ionic polymers [43]. These physical aggregates are held together by non-covalent bonding without perturbation of their tertiary structure that is without denaturation. Subsequent cross-linking of these physical aggregates renders them permanently insoluble while maintaining their preorganized superstructure and hence their catalytic activity. This discovery led to the development of a new family of immobilized enzymes: CLEAs. This type of immobilized enzyme is very effective biocatalysts as they can be produced by inexpensive and effective method. CLEAs can readily be reused and exhibit satisfactory stability and performance for selected applications. The methodology is applicable to essentially any enzyme, including cofactor dependent oxidoreductases [44].

Although the basic methods of enzyme immobilization can be categorized into a few different methods as mentioned above, hundreds of variations, based on combinations of these original methods, have been developed [40,45,46]. Correspondingly, many carriers of different physical and chemical nature or different occurrences have been designed for a variety of bio-immobilizations and bio-separations $[40,47]$.

\section{Choice of support for immobilization}

The characteristics of the matrix are important in determining the performance of the immobilized enzyme system. Ideal support properties include physical resistance to compression, hydrophilicity, inertness toward enzymes ease of derivatization, biocompatibility, resistance to microbial attack, and availability at low cost [48]. Several natural polymer materials like cellulose, alginate, chitin, collagen, carrageenan, chitosan, starch, sepharose, pectin, and other natural polymer materials are commonly used as support materials [40]. Besides, natural polymers various synthetic polymeric materials are also used as support as they possess good mechanical stability, moreover they can be modified easily $[49,50]$. A variety of inorganic supports are also used for the immobilization of enzymes, e.g., alumina, silica, zeolites, and mesoporous silicas [39,40,51]. Silica-based supports are the most suitable matrices for enzyme immobilization in industrial manufacturing of enzyme-processed products [39,52], as well as for research purposes [53]. Carriers which have large surface area always do a great help to obtain good immobilization efficiency.

\section{Nanoparticles as immobilization matrix}

Nanoparticles act as very efficient support materials for enzyme immobilization, because of their ideal characteristics for balancing the key factors that determine biocatalysts efficiency, including specific surface area, mass transfer resistance, and effective enzyme loading [54-57]. Diffusion problem is more relevant when we are dealing with the macromolecular substrates, for such systems the nanoparticles are the ideal candidates [58]. Moreover, the enzyme bound nanoparticles show Brownian movement, when dispersed in aqueous solutions showing that the enzymatic activities are comparatively better than that of the unbound enzyme [55]. In addition, magnetic nanoparticles possess additional advantage, can be separated easily using an external magnetic field. Studies have shown that immobilization of enzymes to the nanoparticles can reduce protein unfolding and can improve stability and performance [55]. Various reviews on immobilization of enzymes on different types of nanoparticles (metal nanoparticles, metal oxide nanoparticles, magnetic nanoparticles, porous and polymeric nanoparticles) have been published earlier [55,56,59,60]. A few examples of nanoimmobilized enzymes are cited in this review.

Enzymatic immobilization on $\mathrm{Au}$ and $\mathrm{Ag}$ nanoparticles have been studied using either as whole cells or isolated enzymes, which include lysozyme [61], glucose oxidase [62], aminopeptidase [63], as well as alcohol dehydrogenase [64]. Cruz et al. [65] reported the Immobilization of enzymes $S$. Carlsberg and Candida antarctica lipase B (CALB) on fumed silica nanoparticles for applications in 
nonaqueous media and they observed catalytic activities were remarkably high. Won et al. [66] immobilized acetylcholinesterase onto magnetic glasses based on iron oxide/silica, for paraoxon sensing. Ganesana et al. [67] performed the immobilization of acetylcholinesterase on nickel nanoparticles and obtained a highly sensitive detection method for organophosphate pesticides. Uygun et al. [68] employed magnetic poly (2-hydroxyethyl methacrylate-Nmethacryloyl-(l)-phenylalanine) to immobilize $\alpha$-amylase. They reported a substrate affinity increases upon enzyme immobilization and showed that a specific activity of $85 \%$ was maintained after 10 reuses. Khoshnevisan et al. [69] immobilized cellulase on magnetic nanoparticles obtaining a smaller activity than for the free enzyme, but at $80^{\circ} \mathrm{C}$ the immobilized enzyme showed slightly greater activity. Lee et al. [70] used amino-functionalized silica-coated magnetic nanoparticles to immobilize trypsin. They applied this system to a pressure-assisted digestion for proteome analysis. It was observed for each of the experiments in which the magnetic nanoparticles were employed an increased number of protein identification in comparison with the experiment with free trypsin. Qiu et al. [71], reported the construction of glucose biosensor using the aminofunctionalized $\mathrm{Fe}_{3} \mathrm{O}_{4} @ \mathrm{SiO}_{2}$ nanoparticles covalently bond to ferrocene monocarboxylic acid as the building block. The biosensor reached $95 \%$ of the steady-state current within $10 \mathrm{~s}$ after the addition of glucose. Recently in our lab we have reported the immobilization of enzymes (Peroxidase, cellulase, trypsin and alpha amylase) on $\mathrm{TiO}_{2}$ nanoparticles. The immobilized enzymes show higher activity than free enzymes. It also showed enhanced thermal stability compared to its soluble counterpart at higher temperature [72-75].

All the advantages of immobilized enzymes on micron-sized particles are inherited when nanomaterials are used as solid supports. Broadly there are four main approaches to link a protein or enzyme to the nanoparticles as shown in Figure 2. (a)

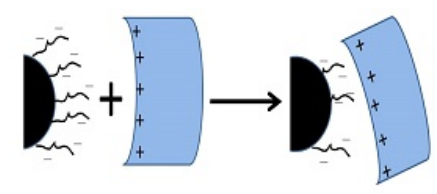

(b)

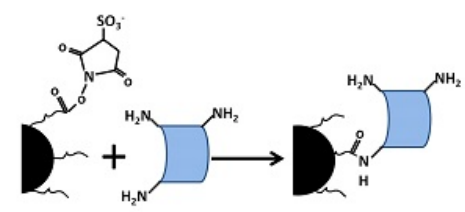

(c)

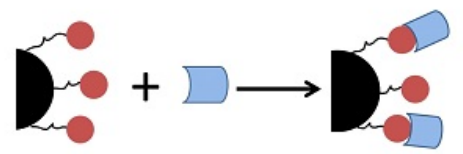

(d)

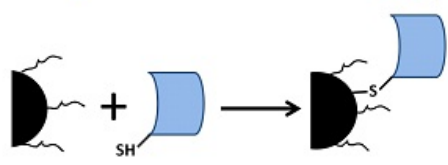

Figure 2: Approaches to link enzymes to nanoparticles: (a) electrostatic adsorption (b) Covalent attachment to the nanoparticle ligand (c) Conjugation using specific affinity of protein (d) Direct conjugation to the nanoparticles surface.
Electrostatic adsorption: The most widely used linkage approach consists of electrostatic adsorption (Figure 2a). This is the simplest approach and is already used routinely as an electron dense marker in histology [76]. The interaction between the nanoparticle and protein may be modulated by the $\mathrm{pH}$ or charge screening by controlling the ionic strength of the medium.

Covalent attachment to the surface modified nanoparticles: Another general method for nanoparticle-protein conjugation is covalently linking a protein to the nanoparticle ligand (Figure 2b). This approach has been greatly advanced by extreme control over the surface chemistry of the nanoparticles. For example, a variety of organic functional groups can be introduced to the surface using mild conditions [77]. The popular labeling chemistry utilizes the covalent binding of primary amines with sulfo-NHS esters or R-COOH groups via reaction with EDC [77]. Nanoparticles labeled with NHS esters can react to form covalent bonds with the primary amine of lysine on a protein. In addition, nanoparticles coated with maleimide groups can react with the thiol of cysteine on a protein. Oxide nanoparticles ( $\mathrm{TiO}$ iron oxide, Coper oxide, silver and gold oxide) can be easily modified by Silanization yielding a modified surface exhibiting amino groups, which can be used as adsorbent or as coupling sites for linking various proteins.

Conjugation using specific affinity of protein: Nanoparticle-protein conjugation can also be achieved by using specific labeling strategies (Figure 2c). Example Streptavidin coated nanoparticles can selectively bind biotin-labeled proteins and antibody coated nanoparticles selectively bind to the specific protein [78].

Direct conjugation to the nanoparticles surface: A direct reaction of a chemical group on the protein without the use of a linker is usually desired if the particle is used as a biosensor where FRET or electron transfer is used (Figure 2d). For Au and Ag nanoparticles, this can be achieved by the Au-thiol or Ag- thiol chemistry where a protein with a cysteine covalently bonds to an $\mathrm{Au}$ or $\mathrm{Ag}$ nanoparticle. The conjugation requires incubation of the protein and the nanoparticle together as the $\mathrm{Au}-\mathrm{S}$ or $\mathrm{Ag}-\mathrm{S}$ bond is strongly favored. Similarly, for sulphur containing nanoparticles such as $\mathrm{ZnS} / \mathrm{CdSe}$, cysteine can directly form a disulfide bridge with the surface $S$ atom. Direct linkages can also be achieved by His tags, which can attach directly to $\mathrm{Zn}, \mathrm{Ni}, \mathrm{Cu}, \mathrm{Co}, \mathrm{Fe}, \mathrm{Mn}$ atoms.

\begin{tabular}{|l|l|}
\hline Advantages & Disadvantages \\
\hline Mass transfer resistance & Cost of fabricational process \\
\hline Effective enzyme loading & Large scale application \\
\hline High surface area & $\begin{array}{l}\text { Separation of the reaction } \\
\text { medium }\end{array}$ \\
\hline High mechanical strength & $\begin{array}{l}\text { (except magnetic } \\
\text { nanoparticles) }\end{array}$ \\
\hline Diffusional problems minimization & \\
\hline
\end{tabular}

Table 1: Advantages and disadvantages of using nanoparticles for enzyme immobilization.

Some important new consequences arise when the size of the carrier approaches nanodimensions. Mostly, these all work out in the favour of using nanosized materials. Table 1 Summarizes the advantages and 
Citation: Ahmad R, Sardar M (2015) Enzyme Immobilization: An Overview on Nanoparticles as Immobilization Matrix. Biochem Anal Biochem 4:

Page 5 of 8

disadvantages of the use of nanoparticles for enzyme immobilization, considering general aspects.

Present studies shows that different types of nanomaterial are avalaible for enzyme immobilization for examples carbon nanotubes (CNTs), nanoparticles, magnetic nanoparticles, mesoporous media, nanofibers, nanocomposites, nanorods and sol-gel materials containing nanometer-size particles and single-enzyme nanoparticles [79]. However, the major problem for their application is their high cost and complex supports preparation [80]. Strategies or protocols for synthesizing the nanoparticles should be developed which are low cost, ecofriendly and can be used for large scale synthesis.

\section{Selected applications of immobilized enzymes}

Industrial applications of immobilized enzymes include laboratoryscale organic synthesis and analytical and medical applications $[48,81]$. Furthermore, since enzymes are able to catalyze reactions not only in aqueous solutions but also inorganic media, immobilized enzymes can catalyze organic synthesis [82]. DiCosimo et al. [5] mentioned many uses for immobilized enzymes, as high-fructose corn syrup production, pectin hydrolysis, debittering of fruit juices, interesterification of food, fats and oils, biodiesel production, carbon dioxide capture and, in most cases, it can be extended to "nano" sizes. Table 2 shows few applications of nanoimmobilized enzymes.

\begin{tabular}{|c|c|c|c|}
\hline Enzyme & Nanoparticle & Application & References \\
\hline \multirow{2}{*}{$\begin{array}{l}\beta \text {-Glucosidase (BGL) from Aspergillus } \\
\text { niger }\end{array}$} & Iron oxide & Biofuel production & [83] \\
\hline & \multicolumn{2}{|l|}{ nanoparticles } & \\
\hline \multirow[t]{2}{*}{ Superoxide dismutase (SOD) } & Nano $\mathrm{Fe}_{3} \mathrm{O}_{4}$ coated & Biosensors & {$[84]$} \\
\hline & \multicolumn{3}{|l|}{ on a gold electrode surface } \\
\hline a-Amylase & Silica nanoparticles & $\begin{array}{l}\text { Formulation of detergent for } \\
\text { enhancing removal of starch } \\
\text { soils }\end{array}$ & {$[85]$} \\
\hline Trypsin & $\begin{array}{l}\text { Nanodiamond prepared by } \\
\text { detonation (dND) }\end{array}$ & Proteolysis & [86] \\
\hline Lysozyme & Chitosan nanofibers & Antibacterial & {$[87]$} \\
\hline Mucor javanicus lipase & Nano-sized magnetite & $\begin{array}{l}\text { Solvent-free synthesis of } 3- \\
\text { diacylglycerols }\end{array}$ & {$[88]$} \\
\hline $\begin{array}{l}\text { Lipases from C. rugosa and } \\
\text { Pseudomonas cepacia }\end{array}$ & Zirconia nanoparticles & $\begin{array}{l}\text { Resolution of }(R, S) \text {-ibuprofen } \\
\text { and }(R, S)-1-\text { phenylethanol, } \\
\text { respectively }\end{array}$ & {$[89]$} \\
\hline Horseradish peroxidase (HRP) & Magnetite silica nanoparticles & Immunoassays & [90] \\
\hline \multirow{2}{*}{$\begin{array}{l}\text { Alcohol dehydrogenase from } \mathrm{T} \text {. brockii } \\
(\mathrm{TbADH})\end{array}$} & Gold and silver & Alcohol synthesis & {$[91]$} \\
\hline & \multicolumn{2}{|l|}{ nanoparticles } & \\
\hline Cholesterol oxidase & $\mathrm{Fe}_{3} \mathrm{O}_{4}$ nanoparticles & $\begin{array}{l}\text { Analysis of total cholesterol in } \\
\text { serum }\end{array}$ & {$[92]$} \\
\hline Haloalkane dehalogenase & $\begin{array}{l}\text { Silica coated iron oxide } \\
\text { nanoparticle }\end{array}$ & $\begin{array}{l}\begin{array}{l}\text { Production of fusion proteins } \\
\text { containing } \\
\text { sequences }\end{array} \\
\text { dehalogenase }\end{array}$ & [93] \\
\hline Laccase & $\begin{array}{l}\text { Chitosan-magnetic } \\
\text { nanoparticle }\end{array}$ & $\begin{array}{l}\text { Bioremediation of environmental } \\
\text { pollutants }\end{array}$ & {$[94]$} \\
\hline Keratinase & $\mathrm{Fe}_{3} \mathrm{O}_{4}$ nanoparticles & Synthesis of keratin & {$[95]$} \\
\hline a-Amylase & $\begin{array}{l}\text { Cellulose-coated magnetite } \\
\text { nanoparticles }\end{array}$ & Starch degradation & {$[96]$} \\
\hline B-Galactosidase & $\begin{array}{l}\text { Con } \quad \text { A layered } \mathrm{ZnO} \\
\text { nanoparticles }\end{array}$ & Lactose hydrolysis & {$[97]$} \\
\hline Lipase & $\mathrm{Fe}_{3} \mathrm{O}_{4}$ nanoparticles & Hydrolysis of pNPP & [98] \\
\hline Glucose oxidase & Thiolated gold nanoparticle & $\begin{array}{l}\text { Estimation of glucose levelup to } \\
300 \mathrm{mg} / \mathrm{ml}\end{array}$ & [99] \\
\hline Lipase & Polystyrene nanoparticle & Aminolysis, esterification, & {$[100]$} \\
\hline
\end{tabular}


Citation: Ahmad R, Sardar M (2015) Enzyme Immobilization: An Overview on Nanoparticles as Immobilization Matrix. Biochem Anal Biochem 4:

Page 6 of 8

\begin{tabular}{|l|l|l|l|l|}
\hline & \multicolumn{2}{|l|}{ trans-esterification } \\
\hline a-Chymotrypsin & Polystyrene nanoparticles & Proteolysis (cleaves peptide & {$[101]$} \\
\hline Diastase & \multicolumn{1}{|l|}{} \\
\hline Bitter Gourd Peroxidase (BGP) & $\begin{array}{l}\text { Silica coated nickel } \\
\text { nanoparticle }\end{array}$ & Starch hydrolysis & {$[102]$} \\
\hline Cellulase & $\mathrm{TiO}_{2}$ nanoprticles & Phenol and dye removal & {$[73]$} \\
\hline Alpha amylase & $\mathrm{TiO}_{2}$ nanoprticles & $\begin{array}{l}\text { Hydrolysis of Carboxy methyl } \\
\text { cellulose }\end{array}$ & {$[75]$} \\
\hline Alpha amylase & $\mathrm{TiO}_{2}$ nanoprticles & Starch hydrolysis & {$[72]$} \\
\hline Trypsin & $\mathrm{TiO}_{2}$ nanoprticles & Starch hydrolysis and refolding & {$[74]$} \\
\hline Alpha amylase & $\mathrm{TiO}_{2}$ nanoprticles & refolding & {$[74]$} \\
\hline
\end{tabular}

Table 2: Enzymes immobilized on nanoparticles and their biotechnological applications.

\section{Conclusions}

Immobilization process has been used for enhancing enzyme activity and stability in aqueous and non-aqueous media. Selecting and designing the support matrix are important in enzyme immobilization. Recently, the use of nanoparticles has emerged as a versatile tool for generating excellent supports for enzyme stabilization due to their small size and large surface area. It has been observed that the stability and activity of enzymes increases when immobilized on such materials. The nanomaterials are key components in the future market of high technology. Nanoparticles strongly influence the mechanical properties of the material like stiffness and elasticity and provide biocompatible environments for enzyme immobilization.

\section{Acknowledgement}

The financial support provided by ICMR, Government of India to Razi Ahmad in the form of SRF is greatly acknowledged.

\section{References}

1. Gomes-Ruffi CR, Cunha RHd, Almeida EL, Chang YK, Steel CJ (2012) Effect of the emulsifier sodium stearoyl lactylate and of the enzyme maltogenic amylase on the quality of pan bread during storage. Lwt-Food Sci Technol 49: 96-101

2. Jaros D, Rohm H (2011) Enzymes exogenous to milk in dairy technology transglutaminase: Encyclopedia of dairy sciences (2ndedn), Academic Press

3. Ismail B, Nielsen SS (2010) Invited review: Plasmin protease in milk: current knowledge and relevance to dairy industry. J Dairy Sci 93 : 4999-5009.

4. Bai Y, Huang H, Meng K, Shi P, Yang P, et al. (2012) Identification of an acidic a-amylase from Alicyclobacillus sp. A4 and assessment of its application in the starch industry. Food Chem 131: 1473-1478

5. DiCosimo R, McAuliffe J, Poulose AJ, Bohlmann G (2013) Industrial use of immobilized enzymes. Chem Soc Rev 42: 6437-6474.

6. Schückel J, Matura A, van Pée KH (2011) One-copper laccase-related enzyme from Marasmius sp.: purification, characterization and bleaching of textile dyes. Enzyme Microb Technol 48: 278-284.
7. Hakala TK, Liitiä T, Suurnäkki A (2013) Enzyme-aided alkaline extraction of oligosaccharides and polymeric xylan from hardwood kraft pulp. Carbohydr Polym 93: 102-108.

8. Rao CS, Sathish T, Ravichandra P, Prakasham RS (2009) Characterization of thermo-and detergent stable serine protease from isolated Bacillus circulans and evaluation of eco-friendly applications. Process Biochem 44: 262-268

9. Apetrei IM, Rodriguez-Mendez ML, Apetrei C, De Saja JA (2013) Enzyme sensor based on carbon nanotubes/cobalt (II) phthalocyanine and tyrosinase used in pharmaceutical analysis. Sens. Actuators b Chemical 177: 138-144

10. Das R, Ghosh S, Bhattacharjee C (2012) Enzyme membrane reactor in isolation of antioxidative peptides from oil industry waste: A comparison with non-peptidic antioxidants. Lwt-Food Sci Technol 47: 238-245

11. Luo K, Yang Q, Yu J, Li XM, Yang GJ, et al. (2011) Combined effect of sodium dodecyl sulfate and enzyme on waste activated sludge hydrolysis and acidification. Bioresour Technol 102: 7103-7110.

12. Tonini D, Astrup T (2012) Life-cycle assessment of a waste refinery process for enzymatic treatment of municipal solid waste. Waste Manag 32: $165-176$

13. Tong Z, Qingxiang Z, Hui H, Qin L, Yi Z (1997) Removal of toxic phenol and 4-chlorophenol from waste water by horseradish peroxidase. Chemosphere 34: 893-903

14. Akhtar S, Husain Q (2006) Potential applications of immobilized bitter gourd (Momordica charantia) peroxidase in the removal of phenols from polluted water. Chemosphere 65: 1228-1235.

15. Akhtar S, Khan AA, Husain Q (2005) Partially purified bitter gourd (Momordica charantia) peroxidase catalyzed decolorization of textile and other industrially important dyes. Bioresour Technol 96: 1804-1811

16. Atadashi IM, Aroua MK, Aziz AA (2010) High quality biodiesel and its diesel engine application: a review. Renewable and Sustainable Energy Reviews 14: 1999-2008

17. Nelson JM, Griffin EG (1916) Adsorption of Invertase. J Am Chem Soc 38: 1109-1115

18. Brady D, Jordaan J (2009) Advances in enzyme immobilisation. Biotechnol Lett 31: 1639-1650.

19. Cantone S, Ferrario V, Corici L, Ebert C, Fattor D, et al. (2013) Efficient immobilisation of industrial biocatalysts: criteria and constraints for the selection of organic polymeric carriers and immobilisation methods. Chem Soc Rev 42: 6262-6276

20. Cherry JR, Fidantsef AL (2003) Directed evolution of industrial enzymes: an update. Curr Opin Biotechnol 14: 438-443. 
21. Massolini G, Calleri E (2005) Immobilized trypsin systems coupled online to separation methods: recent developments and analytical applications. J Sep Sci 28: 7-21.

22. Guzik U, Hupert-Kocurek K, WojcieszyÅ,ska D (2014) Immobilization as a strategy for improving enzyme properties-application to oxidoreductases. Molecules 19: 8995-9018.

23. Rodrigues RC Ortiz C, Berenguer-Murcia Á, Torres R, FernándezLafuente R (2013) Modifying enzyme activity and selectivity by immobilization. Chem Soc Rev 42: 6290-6307.

24. Secundo F (2013) Conformational changes of enzymes upon immobilisation. Chem Soc Rev 42: 6250-6261.

25. Liese A, Hilterhaus L (2013) Evaluation of immobilized enzymes for industrial applications. Chem Soc Rev 42: 6236-6249.

26. Mateo C, Palomo JM, Fernandez-Lorente G, Guisan JM, FernandezLafuente R (2007) Improvement of enzyme activity, stability and selectivity via immobilization techniques. Enzyme Microb Technol 40: 1451-1463

27. Ursini A, Maragni P, Bismara C, Tamburini B (1999) Enzymatic method of preparation of optically active trans-2-amtno cyclohexanol derivatives. Synth Commun 29: 1369-1377

28. Goto M, Hatanaka C, Goto M (2005) Immobilization of surfactant-lipase complexes and their high heat resistance in organic media. Biochem Eng J 24: 91-94

29. Janssen MH van Langen LM, Pereira SR, van Rantwijk F, Sheldon RA (2002) Evaluation of the performance of immobilized penicillin G acylase using active-site titration. Biotechnol Bioeng 78: 425-432.

30. Rodrigues RC, Berenguer-Murcia A, Fernandez-Lafuente R (2011) Coupling chemical modification and immobilization to improve the catalytic performance of enzymes. Adv Synth Catal 353: 2216-2238

31. Garcia-Galan C, Berenguer-Murcia A, Fernandez-Lafuente R, Rodrigues RC (2011) Potential of different enzyme immobilization strategies to improve enzyme performance. Adv Synth Catal 353: 2885-2904

32. Sheldon RA van Pelt S (2013) Enzyme immobilisation in biocatalysis: why, what and how. Chem Soc Rev 42: 6223-6235.

33. Spahn C, Minteer SD (2008) Enzyme immobilization in biotechnology. Recent Pat Eng 2: 195-200

34. Johnson RD, Wang ZG, Arnold FH (1996) Surface site heterogeneity and lateral interactions in multipoint protein adsorption. J. Phys. Chem. 100: 5134-5139

35. Rao SV, Anderson KW, Bachas LG (1998) Oriented immobilization of proteins. Microchimica Acta 128: 127-143

36. D'Souza SF (1999) Immobilized enzymes in bioprocess. Curr Sci 77: 69-79

37. Fu J, Reinhold J, Woodbury NW (2011) Peptide-modified surfaces for enzyme immobilization. PLoS One 6: e18692.

38. Singh V, Sardar M, Gupta MN (2013) Immobilization of Enzymes by Bioaffinity Layering. In: Immobilization of Enzymes and Cells. (3rdedn), Springer, Humana Press

39. Hartmann M, Kostrov X (2013) Immobilization of enzymes on porous silicas--benefits and challenges. Chem Soc Rev 42: 6277-6289.

40. Datta S, Christena LR, Rajaram YRS (2013) Enzyme immobilization: an overview on techniques and support materials. 3 Biotech 3: 1-9

41. Grosová Z, Rosenberg M, Rebros M, Sipocz M, Sedlácková B (2008) Entrapment of beta-galactosidase in polyvinylalcohol hydrogel. Biotechnol Lett 30: 763-767.

42. Deshpande A, D'souza SF, Nadkarni GB (1987) Coimmobilization of Damino acid oxidase and catalase by entrapment of Trigonopsis variabilis in radiation polymerised Polyacrylamide beads. Journal of bioscience 11: 137-144

43. Sheldon RA (2007) Cross-linked enzyme aggregates (CLEAs): stable and recyclable biocatalysts. Biochem Soc Trans 35: 1583-1587.

44. Sheldon RA (2007) Enzyme immobilization: the quest for optimum performance. Adv Synth Catal 349: 1289-1307

45. Katzbauer B, Narodoslawsky M, Moser A (1995) Classification system for immobilization techniques. Bioprocess. Eng 12: 173-179
46. Homaei AA, Sariri R, Vianello F, Stevanato R (2013) Enzyme immobilization: an update. J Chem Biol 6: 185-205.

47. White CA, Kennedy JF (1980) Popular matrices for enzyme and other immobilizations. Enzyme Microb Technol 2: 82-90

48. Brena BM, Batista-Viera F (2006) Immobilization of enzymes. In Immobilization of enzymes and cells. Springer 15-30

49. Yong Y, Bai Y-X, Li Y-F, Lin L, Cui Y-J, et al. (2008) Characterization of Candida rugosa lipase immobilized onto magnetic microspheres with hydrophilicity. Process Biochem 43: 1179-1185

50. Bryjak J, Trochimczuk AW (2006) Immobilization of lipase and penicillin acylase on hydrophobic acrylic carriers. Enzyme Microb. Technol 39: 573-578

51. Hudson S, Cooney J, Magner E (2008) Proteins in mesoporous silicates. Angew Chem Int Ed Engl 47: 8582-8594.

52. Ho L-F, Li S-Y, Lin S-C, Hsu W-H (2004) Integrated enzyme purification and immobilization processes with immobilized metal affinity adsorbents. Process Biochem 39: 1573-1581

53. Vianello F, Zennaro L, Di Paolo ML, Rigo A, Malacarne C, et al. (2000) Preparation, morphological characterization, and activity of thin films of horseradish peroxidase. Biotechnol Bioeng 68: 488-495.

54. Feng W, Ji P (2011) Enzymes immobilized on carbon nanotubes. Biotechnol Adv 29: 889-895.

55. Gupta MN, Kaloti M, Kapoor M, Solanki K (2011) Nanomaterials as matrices for enzyme immobilization. Artif Cells Blood Substit Immobil Biotechnol 39: 98-109.

56. Ansari SA, Husain Q (2012) Potential applications of enzymes immobilized on/in nano materials: A review. Biotechnol Adv 30: 512-523.

57. Verma ML, Barrow CJ, Puri M (2013) Nanobiotechnology as a novel paradigm for enzyme immobilisation and stabilisation with potential applications in biodiesel production. Appl Microbiol Biotechnol 97: 23-39.

58. Hwang ET, Gu MB (2013) Enzyme stabilization by nano/microsized hybrid materials. Engineering in Life Sciences 13: 49-61

59. Cipolatti EP, Silva MJ, Klein M, Feddern V, Feltes MMC, et al. (2014) Current status and trends in enzymatic nanoimmobilization. J Mol Catal B: Enzym 99: 56-67

60. Min K, Yoo YJ (2014) Recent progress in nanobiocatalysis for enzyme immobilization and its application. Biotechnology and Bioprocess Engineering 19: 553-567

61. Vertegel AA, Siegel RW, Dordick JS (2004) Silica nanoparticle size influences the structure and enzymatic activity of adsorbed lysozyme. Langmuir 20: 6800-6807.

62. Lan D, Li B, Zhang Z (2008) Chemiluminescence flow biosensor for glucose based on gold nanoparticle-enhanced activities of glucose oxidase and horseradish peroxidase. Biosens Bioelectron 24: 940-944.

63. Wu C-L, Chen Y-P, Yang J-C, Lo H-F, Lin L-L (2008) Characterization of lysine-tagged Bacillus stearothermophilus leucine aminopeptidase II immobilized onto carboxylated gold nanoparticles. J Mol Catal B: Enzym 54: 83-89

64. Keighron JD, Keating CD (2010) Enzyme: nanoparticle bioconjugates with two sequential enzymes: stoichiometry and activity of malate dehydrogenase and citrate synthase on Au nanoparticles. Langmuir 26: $18992-19000$

65. Cruz JC, Würges K, Kramer M, Pfromm PH, Rezac ME, et al. (2011) Immobilization of enzymes on fumed silica nanoparticles for applications in nonaqueous media. Methods Mol Biol 743: 147-160.

66. Won YH, Jang HS, Kim SM, Stach E, Ganesana M, et al. (2010) Biomagnetic glasses: preparation, characterization, and biosensor applications. Langmuir 26: 4320-4326.

67. Ganesana M, Istarnboulie G, Marty J-L, Noguer T, Andreescu S (2011) Site-specific immobilization of a (His) 6-tagged acetylcholinesterase on nickel nanoparticles for highly sensitive toxicity biosensors. Biosens Bioelectron 30: 43-48 
68. Uygun DA, ozturk N, Akgol S, Denizli A (2012) Novel magnetic nanoparticles for the hydrolysis of starch with Bacillus licheniformis aamylase. J Appl Polym Sci 123: 2574-2581

69. Khoshnevisan K, Bordbar A-K, Zare D, Davoodi D, Noruzi M, et al. (2011) Immobilization of cellulase enzyme on superparamagnetic nanoparticles and determination of its activity and stability. Chem Eng J 171: 669-673

70. Lee B, Lopez-Ferrer D, Kim BC, Na HB, Park YI, et al. (2011) Rapid and efficient protein digestion using trypsin-coated magnetic nanoparticles under pressure cycles. Proteomics 11: 309-318

71. Qiu J, Peng H, Liang R (2007) Ferrocene-modified Fe3O4@ SiO2 magnetic nanoparticles as building blocks for construction of reagentless enzyme-based biosensors. Electrochem. Commun. 9: 2734-2738

72. Ahmad R, Khatoon N, Sardar M (2013) Biosynthesis, Characterization and Application of $\mathrm{TiO} 2$ nanoparticles in biocatalysis and protein folding. J. Proteins Proteomics 4: 115-121

73. Ahmad R, Mishra A, Sardar M (2013) Peroxidase-TiO2 nanobioconjugates for the removal of phenols and dyes from aqueous solutions. Adv Sci Eng Med 5: 1020-1025

74. Ahmad R, Mishra A, Sardar M (2014) Simultaneous Immobilization and Refolding of Heat Treated Enzymes on TiO2 Nanoparticles. Adv Sci Eng Med 6: 1264-1268

75. Ahmad R, Sardar M (2014) Immobilization of cellulase on $\mathrm{TiO} 2$ nanoparticles by physical and covalent methods: a comparative study. Indian J Biochem Biophys 51: 314-320.

76. Geoghegan WD, Ackerman GA (1977) Adsorption of horseradish peroxidase, ovomucoid and anti-immunoglobulin to colloidal gold for the indirect detection of concanavalin $\mathrm{A}$, wheat germ agglutinin and goat anti-human immunoglobulin $G$ on cell surfaces at the electron microscopic level: a new method, theory and application. J Histochem Cytochem 25: 1187-1200

77. Aubin-Tam ME, Hamad-Schifferli K (2008) Structure and function of nanoparticle-protein conjugates. Biomed Mater 3: 034001.

78. Di Marco M, Shamsuddin S, Razak KA, Aziz AA, Devaux C, et al. (2010) Overview of the main methods used to combine proteins with nanosystems: absorption, bioconjugation, and encapsulation. Int $\mathrm{J}$ Nanomedicine 5: 37-49.

79. Andreescu S, Njagi J, Ispas C (2007) Nanostructured materials for enzyme immobilization and biosensors: The New Frontiers of Organic and Composite Nanotechnology. Elsevier, USA

80. Dong H, Li J, Li Y, Hu L, Luo D (2012) Improvement of catalytic activity and stability of lipase by immobilization on organobentonite. Chem Eng J 181: 590-596

81. Taylor IN, Brown RC, Bycroft M, King G, Littlechild JA, et al. (2004) Application of thermophilic enzymes in commercial biotransformation processes. Biochem Soc Trans 32: 290-292.

82. Carrea G, Riva S (2000) Properties and Synthetic Applications of Enzymes in Organic Solvents. Angew Chem Int Ed Engl 39: 2226-2254.

83. Verma ML, Chaudhary R, Tsuzuki T, Barrow CJ, Puri M (2013) Immobilization of $B$-glucosidase on a magnetic nanoparticle improves thermostability: application in cellobiose hydrolysis. Bioresour Technol 135: 2-6

84. Thandavan K, Gandhi S, Sethuraman S, Rayappan JB, Krishnan UM (2013) Development of electrochemical biosensor with nano-interface for xanthine sensing--a novel approach for fish freshness estimation. Food Chem 139: 963-969.
85. Soleimani M, Khani A, Najafzadeh K (2012) a-Amylase immobilization on the silica nanoparticles for cleaning performance towards starch soils in laundry detergents. J Mol Catal B: Enzym 74: 1-5

86. Wei L, Zhang W, Lu H, Yang P (2010) Immobilization of enzyme on detonation nanodiamond for highly efficient proteolysis. Talanta 80 : 1298-1304.

87. Park JM, Kim M, Park HS, Jang A, Min J, et al. (2013) Immobilization of lysozyme-CLEA onto electrospun chitosan nanofiber for effective antibacterial applications. Int J Biol Macromol 54: 37-43.

88. Meng X, Xu G, Zhou QL, Wu JP, Yang LR (2014) Highly efficient solvent-free synthesis of 3-diacylglycerols by lipase immobilised on nanosized magnetite particles. Food Chem 143: 319-324.

89. Chen YZ, Yang CT, Ching CB, Xu R (2008) Immobilization of lipases on hydrophobilized zirconia nanoparticles: highly enantioselective and reusable biocatalysts. Langmuir 24: 8877-8884.

90. Yang H-H, Zhang S-Q, Chen X-L, Zhuang Z-X, Xu J-G, et al. (2004) Magnetite-containing spherical silica nanoparticles for biocatalysis and bioseparations. Analytical chemistry 76: 1316-1321

91. Petkova GA, Záruba CK, Zvátora P, Král V (2012) Gold and silver nanoparticles for biomolecule immobilization and enzymatic catalysis. Nanoscale Res Lett 7: 287.

92. Kouassi GK, Irudayaraj J, McCarty G (2005) Examination of Cholesterol oxidase attachment to magnetic nanoparticles. J Nanobiotechnology 3: 1.

93. Johnson AK, Zawadzka AM, Deobald LA, Crawford RL, Paszczynski AJ (2008) Novel method for immobilization of enzymes to magnetic nanoparticles. J Nanopart Res 10: 1009-1025

94. Kalkan NA, Aksoy S, Aksoy EA, Hasirci N (2012) Preparation of chitosan-coated magnetite nanoparticles and application for immobilization of laccase. J Appl Polym Sci 123: 707-716

95. Konwarh R, Karak N, Rai SK, Mukherjee AK (2009) Polymer-assisted iron oxide magnetic nanoparticle immobilized keratinase. Nanotechnology 20: 225107.

96. Namdeo M, Bajpai SK (2009) Immobilization of a-amylase onto cellulose-coated magnetite (CCM) nanoparticles and preliminary starch degradation study. J Mol Catal B: Enzym 59: 134-139

97. Ansari SA, Husain Q, Qayyum S, Azam A (2011) Designing and surface modification of zinc oxide nanoparticles for biomedical applications. Food Chem Toxicol 49: 2107-2115.

98. Huang SH, Liao MH, Chen DH (2003) Direct binding and characterization of lipase onto magnetic nanoparticles. Biotechnol Prog 19: $1095-1100$

99. Pandey P, Singh SP, Arya SK, Gupta V, Datta M, et al. (2007) Application of thiolated gold nanoparticles for the enhancement of glucose oxidase activity. Langmuir 23: 3333-3337.

100. MiletiÄ $\ddagger$ N, Abetz V, Ebert K, Loos K (2010) Immobilization of Candida antarctica lipase B on Polystyrene Nanoparticles. Macromol Rapid Commun 31: 71-74.

101. Jia H, Zhu G, Wang P (2003) Catalytic behaviors of enzymes attached to nanoparticles: the effect of particle mobility. Biotechnol Bioeng 84: 406-414.

102. Prakasham RS, Devi GS, Laxmi KR, Rao CS (2007) Novel synthesis of ferric impregnated silica nanoparticles and their evaluation as a matrix for enzyme immobilization. J Phys Chem C 111: 3842-3847

103. Mishra A, Ahmad R, Singh V, Gupta MN, Sardar M (2013) Preparation, characterization and biocatalytic activity of a nanoconjugate of alpha amylase and silver nanoparticles. J Nanosci Nanotechnol 13: 5028-5033. 